\title{
EFFECT OF NON DENTAL GLASS FIBER ORIENTATION ON TRANSVERSE STRENGTH OF DENTAL FIBER REINFORCED COMPOSITE
}

\author{
Abdulghani Ali Khalil \\ Faculty of Dentistry of Universitas Gadjah Mada \\ Email: ass_entr13@yahoo.com \\ Widowati Siswomiharjo dan Siti Sunarintyas \\ Biomaterial Department, Faculty of Dentistry of Universitas Gadjah Mada
}

\begin{abstract}
ABSTRAK
FRC banyak digunakkan dalam kedoketeran gigi khususnya untuk bridge konstruksi. E glass fiber sering digunakan karna memiliki sifat yang baik dan berikatan baik dengan polimer. Di Indonesia E-glass terbatas dengan harga cukup mahal. Glass fiber non dental banyak tersedia di Indonesia dengan harga terjangkau. Tujuan penelitian ini adalah mengetahui pengaruh orientasi glass fiber non dental pada kekuatan transversa pada gigi FRC. Bahan yang digunakan dalam penelitian ini adalah glass fiber non dental (HJ, China), flowable komposit (CharmFil Flow, DenKist, Korea), Silane coupling agent (Monobond S, Ivoclar Vivadent, Liechtenstein) dan Aquades. Subjek dibagi dalam 2 kelompok. Specimen direndam dalam air selama 24 jam dan 7 hari. Data dianalisis dengan Independent sample T-test. Hasil T-test menunjukkan perbedaan kekuatan transversa dengan 24 jam air perendaman yang signifikan antara dua kelompok orientasi ( $\mathrm{p}<$ $0,05)$. Data dari 7 hari perendaman tidak ada perbdaan statistik antara kelompok ( $p>0,05)$. Kesimpulan: ada perbedaan kekuatan transversa antara roving dan woven roving orientasi di gigi FRC.
\end{abstract}

Kata Kunci: Fiber reinforced composite; Glass fiber non dental; Kekuatan transversa; Orientasi fiber.

\begin{abstract}
FRC is widely used in dentistry especially for dental bridges construction. E glass fiber is commonly used because it has good properties and good bonding with polymers. Its availability is limited and its price quite expensive in Indonesia. Non dental glass fiber is available in Indonesia with lower price. The aim of this research was to evaluate the effect of non dental glass fiber orientation on transverse strength of dental FRC. Non dental glass fiber (HJ, China) with two orientations (Roving and Woven roving), Flowable composite (CharmFil Flow, DenKist, Korea), Silane coupling agent (Monobond S, Ivoclar Vivadent, Liechtenstein) and distilled water. 24 specimens of non dental glass FRC, divided into 2 groups. The specimens was immersed in water for 24 hours and 7 days. The data were analyzed by Independent sample T-test. T-test analysis showed that for transverse strength with 24 hours water immersion there was a significant difference between the two orientation groups ( $p<0.05)$. The data of 7 days immersion there was no statistical difference between the groups $(p>0.05)$. In conclusion: there was different transverse strength between roving and woven roving orientation in dental FRC.
\end{abstract}

Keywords: Fiber orientation; Fiber reinforced composite; Non dental glass fiber; Transverse strength. 


\section{INTRODUCTION}

Composites are materials that comprise strong load carrying material which is known as reinforcement embedded in weaker material which is known as matrix or binder (organic or inorganic) also maintains the position and orientation of the reinforcement (Hull and Clyne, 1996). Fiber reinforced composite materials consist of fibers of high strength and modulus embedded in or bonded to a matrix with distinct interfaces (boundaries) between them. Fibers are the principal load carrying members, while the surrounding matrix keeps them in the desired location and orientation (Mallick, 2008). The reinforcing fibers may be introduced into the matrix in a number of orientations. Randomly oriented fibers having a small aspect ratio typical of fiber glass are easily introduced into the matrix and give relatively isotropic behavior in the composite. Long or even continuous unidirectional arrangements of fibers give anisotropic properties (Starr,1995).

The strength of unidirectional reinforced composite material is linked to the main orientation of the fibers, longitudinal or transversal. The most used fibers (glass, carbon, and polyethylene) approximately have a linear elastic behavior until fracture they have a much higher stiffness and strength than the composite matrix (Van Heumen, 2010). Glass fibers are the most common form of all used fibers; they improve mechanical properties of denture base polymers, have easy manipulation and they are esthetic (Uzun et al., 1999 and Kim et al., 2004). There is another type of glass fiber that is available in Indonesia called Non-dental glass fiber. It is widely used to make sculpture, panel gypsum, and automotive component. The composition of non-dental glass fiber with XRF test shows similar composition to E-glass fiber with presence of different components (Table 1).

Non-dental glass fiber is available with three orientations; mats, roving, and woven roving (figure 1). Furthermore, most of dental FRC applications in Indonesia use Polyethylene fiber as an alternative to dental E-glass fiber because of its availability. A group of untwisted parallel strands wound on a cylin- drical forming package is called roving, rovings can be preimpregnated with a thin layer of polymeric resin matrix. Glass fibers are also available in woven roving which is a coarse drapable fabric in which continuous rovings are woven in two mutually perpendicular directions (Mallik, 2008).

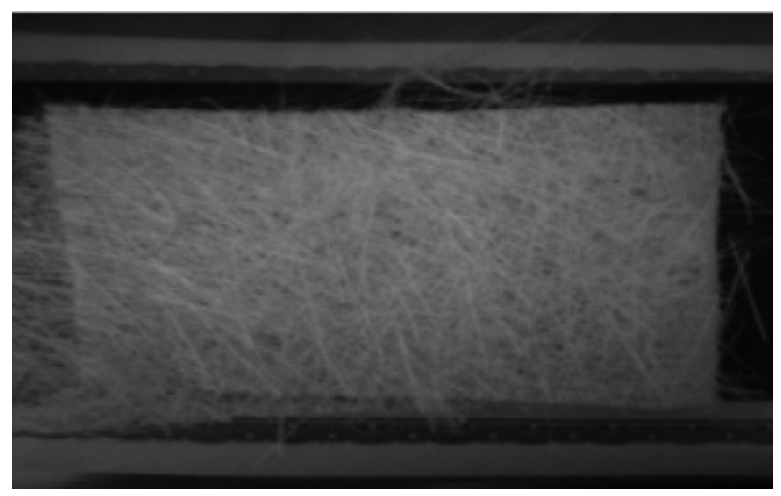

(a)

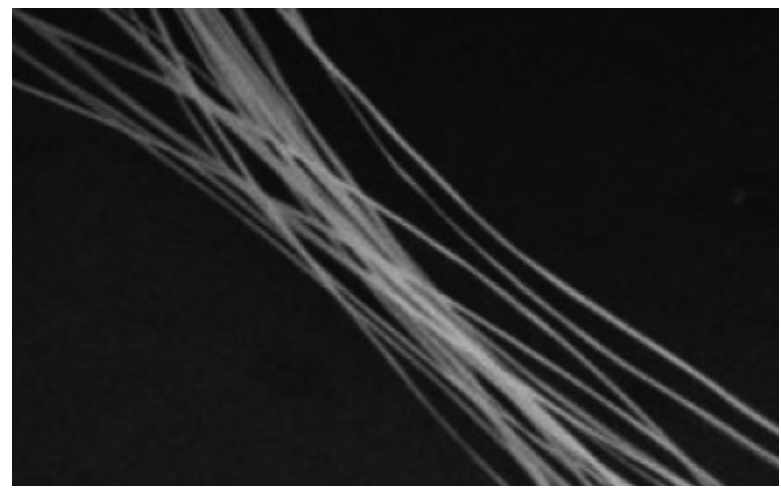

(b)

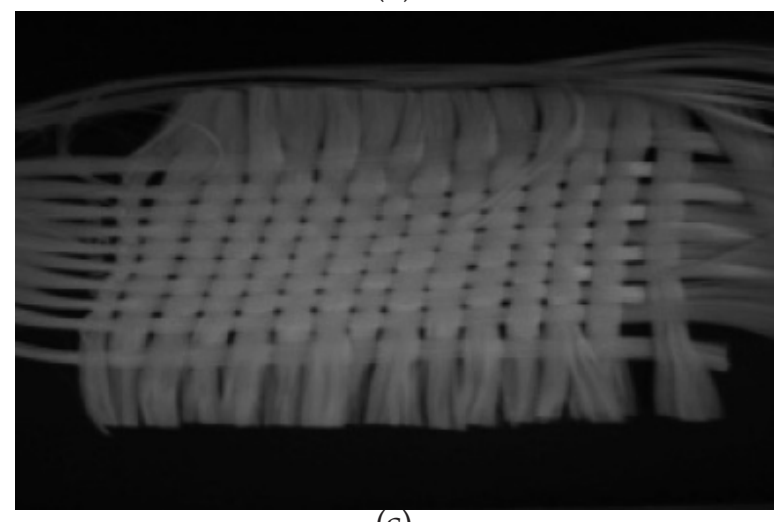

(c)

Figure.1

Non-dental glass fiber with its orientations

(a) random mats non dental glass fiber

(b) unidirectional roving non dental glass fiber

(c) woven roving non dental glass fiber 
Table 1

Composition of glass fiber (\%)

\begin{tabular}{lll}
\hline Component & $\begin{array}{c}\text { Dental E-glass } \\
\text { fiber }\end{array}$ & $\begin{array}{c}\text { Non dental } \\
\text { glass fiber }\end{array}$ \\
\hline & & Woven roving \\
\hline $\mathrm{SiO}_{2}$ & 45.47 & 55.86 \\
$\mathrm{CaO}$ & 38.49 & 18.71 \\
$\mathrm{Na}_{2} \mathrm{O}$ & - & 11.80 \\
$\mathrm{Al}_{2} \mathrm{O}_{3}$ & 12.11 & 5.51 \\
$\mathrm{MgO} \mathrm{O}_{2}$ & - & 5.11 \\
$\mathrm{Fe}_{2} \mathrm{O}_{3}$ & 1.04 & 0.41 \\
$\mathrm{P}_{2} \mathrm{O}_{5}$ & 0.62 & 0.62 \\
$\mathrm{Cl}$ & 0.51 & 0.55 \\
$\mathrm{SO}_{3}$ & 0.43 & 0.70 \\
$\mathrm{~K}_{2} \mathrm{O}$ & 0.94 & 0.32 \\
$\mathrm{TiO}_{2}$ & - & 0.19 \\
$\mathrm{CeO}_{2}$ & - & 0.10 \\
$\mathrm{ZrO}_{2}$ & - & 0.04 \\
$\mathrm{SrO}^{2}$ & 0.18 & - \\
$\mathrm{Cr}_{2} \mathrm{O}_{3}$ & 0.05 & 0.02 \\
$\mathrm{MnO}$ & 0.03 & 0.02 \\
$\mathrm{Rb}_{2} \mathrm{O}$ & 0.02 & - \\
$\mathrm{CuO}^{\mathrm{Bi}} \mathrm{O}_{3}$ & 0.02 & - \\
$\mathrm{ZnO}$ & 0.01 & - \\
& 0.01 & - \\
\hline
\end{tabular}

The unidirectional continuous fibers are anisotropic that can have advantages in various applications. Bidirectional fibers are available in various textile structures for example linen and twill weave. This type of fibers give orthotropic properties. One example of the bidirectional reinforcement is fiber weave, random or chopped oriented fiber give isotropic properties. The glass fiber can be arranged in different directions. Unidirectional glass fiber is stronger (has greater strength) than bidirectional fiber (Tezvergil et al., 2003). The unidirectional orientation of continuous fibers in the composite produces the highest strength and modulus in the transverse to the fiber direction (Mallick, 2008).

Over the last few years the development of fiber reinforced composite (FRC) has offered the dental profession the possibility of fabricating resin-bonded, esthetically good and metalfree tooth restorations for single and multiple teeth replacement. FRC-fixed partial denture (FPD) could be an alternative to metal frame resin bonded-FPD, and also to full-coveragecrown retained FPD and implant supported crowns (Butterworth et al., 2003 and vallittu et al., 2000). The most fibers used are (glass, carbon, and polyethylene) approximately have a linear elastic behavior until fracture they have a much higher stiffness and strength than the composite matrix (Van Heumen, 2010).

Transverse strength, flexural strength, or modulus of rupture, as this property is variously called, is essentially a strength test of a bar supported at each end, or a thin disk supported along a lower support circle under a static load (Anusavice, 2003). Transverse strength is a meaningful mechanical property for brittle materials, although the results cannot be extrapolated to the clinical behavior without considering some aspects, namely flaw distribution (Loughran et al., 2005). In the oral cavity restorations are subjected to various stresses and thus, are required to have adequate strength to function under appropriate physiological loads (ADA,2003). For brittle materials such as ceramics, flexure tests are preferred to the diametral compressive test because they more closely simulate the stress distributions in dental prostheses, this test can be done by using the Universal Testing Machine (Anusavice, 2003).

Unalan et al., (2010) found the transverse strength value of specimens which reinforced with woven fibers was significantly higher than that of continuous unidirectional glass fibers. Tanwer (2014) studied the mechanical properties testing of Unidirectional and Bidirectional glass fiber reinforced Epoxy based composites and found that the Unidirectional specimen has tensile strength $(16.87 \mathrm{MPa})$ compared with Bi-directional specimen which has (8.07 MPa). The purpose of this study was to investigate the effect of orientation of non dental glass fiber (Woven roving and Roving) on transverse strength of dental fiber reinforced composite.

\section{Materials and Methods}

The materials used in this research was Non- dental glass fiber (HJ, China) with two orientations (Roving as unidirectional and 
Woven roving as bidirectional), Flowable composite (CharmFil Flow, DenKist, Korea) and Silane coupling agent (Monobond S, Ivoclar Vivadent, Liechtenstein) and distilled water. This study was performed 24 specimens of non dental glass fiber reinforced composite, divided into two groups for transverse test (Roving and Woven roving orientation).

Metallic mold measuring of $(25 \times 2 \times 2)$ $\mathrm{mm}$, according to the ISO 10477:2004 was prepared for fabrication of specimens. The non dental glass fiber with $24 \mathrm{~mm}$ measured by a ruler and cut by using the scissors. Then the fibers stored in desiccators for 24 hours. A thin layer of composite was applied into metallic mold to retch the middle of mold then, the non dental glass fiber which is already spread with $10 \mu \mathrm{l}$ silane sink into the layer of composite by using the Tweezers, then a thin layer of composite reapply until the metallic mold full, after that the surface sample covered with celluloid strip and irradiate with LED light curing unit for 40 seconds. The cured specimens removed from metallic mold and dry it and finishing it.
The specimens stored in water for 24 hours and 7 days.

Transverse tests were conducted according to ISO 10477: 2004. Universal testing machine (Tokyo Testing Machine, Japan) was used to carry out three point bending test with a span of $20 \mathrm{~mm}$ between supports. The load was applied to the specimen at cross-head speed until the specimen fractures. The following equation can calculate the flexural strength: (Anusavice, 2003).

$$
\sigma=(3 P . L) / 2 b d^{2}
$$

where $\sigma$ was the transverse strength $(\mathrm{MPa})$, $\mathrm{P}$ was the maximum load at the point of fracture $(\mathrm{N})$, L was the distance between the supports $(\mathrm{mm}), \mathrm{b}$ was the width of the specimen $(\mathrm{mm})$, and $\mathrm{d}$ was the thickness of the specimen $(\mathrm{mm})$.

\section{RESULTS AND DISCUSSION}

The result of the transverse strength measurement was as tables:

Table 2

Mean and standard deviation for transverse strength in $\mathrm{MPa}$

\begin{tabular}{|c|c|c|c|c|}
\hline \multirow[t]{2}{*}{ Groups of fibers } & \multicolumn{2}{|c|}{ Transverse strength 24 hours } & \multicolumn{2}{|c|}{ Transverse strength 7 days } \\
\hline & Mean & s.d & Mean & s.d \\
\hline Roving & 152.998 & 8.767 & 133.623 & 30.180 \\
\hline woven roving & 178.436 & 23.362 & 145.373 & 35.859 \\
\hline
\end{tabular}

Table 2 showed the means and the standard deviation of transverse strength groups for both specimens with and without water sorption. The woven roving group with 24 hours obtained the first rank in transverse strength with mean $178.436 \pm 23.362 \mathrm{MPa}$, while the roving group got the second rank with mean $152.998 \pm 8.767 \mathrm{MPa}$. On the other hand woven roving group with 7 (seven) days got the third rank in transverse strength with mean $145.373 \pm 35.859 \mathrm{MPa}$, then the last group was roving group with mean $133.623 \pm 30.180 \mathrm{MPa}$. Independent sample T-test used to examine the effect of non dental glass fiber orientation on the transverse strength of fiber reinforced composite and the results as in Tables below:

Table 3

The result of $\mathrm{t}$-test (effect of fiber orientation on transverse strength $24 \mathrm{~h}$ )

\begin{tabular}{lllll}
\hline \multicolumn{1}{c}{ Flexural strength } & \multicolumn{1}{c}{ t } & & Df & \multicolumn{1}{c}{ Sig (2-tailed) } \\
\hline Equal variance assumed & $-2.497-$ & 10 & 0.032 \\
\hline Equal variance not assumed & $-2.497-$ & 6.381 & 0.044 \\
\hline
\end{tabular}


For the effect of fiber orientation on transverse strength for the specimens which immersed in distilled water for 24 hours and as it is explained in Table 3 there is a statistical difference between fiber orientation groups because the $p$-value $<0.05$.

Table 4

The result of t-test (effect of fiber orientation on transverse strength 7 days)

\begin{tabular}{lllll}
\hline \multicolumn{1}{c}{ Flexural strength } & \multicolumn{1}{c}{ t } & & Df & \multicolumn{1}{c}{ Sig (2-tailed) } \\
\hline Equal variance assumed & $-0.614-$ & 10 & 0.553 \\
\hline Equal variance not assumed & $-0.614-$ & 9.717 & 0.553 \\
\hline
\end{tabular}

By The Table 4 it can be said that there is no statistical difference because $p>0.05$. To compare the result of this research with the control group we tested 12 samples of dental E-glass fiber with unidirectional orientation and the result in Table 5. By the table 5 the dental glass fiber specimens with 24 hours water immersion achieved transverse strength $167.065 \pm 7.328 \mathrm{MPa}$ while with 7 days immersion in water the transverse strength was $120.0017 \pm 18.349 \mathrm{MPa}$.

\section{Table 5}

Mean and standard deviation for transverse strength of dental fiber group in $\mathrm{MPa}$.

\begin{tabular}{lll}
\hline & Mean & s.d \\
Transverse strength 24 h & 167.065 & 7.328 \\
Transverse strength 7 d & 120.0017 & 18.349 \\
\hline
\end{tabular}

Table 3 showed the result of t-test for the effect of fiber orientation on transverse strength for the specimens which has been immersion in water for a period of 24 hours and according to that result there a statistical difference between non dental glass fiber groups because the $p$-value was 0.032 which less than the chosen alpha level $p<0.05$. The mechanical properties of fiber reinforced composite such as stiffness, strength, and fatigue resistant depend upon the geometry of resin reinforcement, mechanical properties of glass fiber reinforced composite structure with continuous unidirectional fiber can express improved results compared to reinforcement with others such as short and random fibers. The reinforcing properties of unidirectional fibers can be obtained in one direction (Khan et al., 2015). In this study as previously mentioned in Table 2 the mean of transverse strength for both uni- directional and bidirectional non dental glass fiber reinforced composite and in this case bidirectional orientation achieved high mean with $178.436 \pm 23.362 \mathrm{MPa}$ comparing with unidirectional mean of $152.998 \pm 8.767 \mathrm{MPa}$.

In a study by Unalan et al., (2010) they found the transverse strength value of specimens which reinforced with woven fibers was significantly higher than that of continuous unidirectional glass fibers. Comparing to our research this difference maybe as a result of limitations of laboratory work and presence of some pores in the samples based on optical microscopic test which showed non dental glass fiber roving samples have more pores than the non dental glass fiber woven roving (figure 2). In case of bidirectional orientation, the fiber is locked together so the stress is transferred to the fiber through the fiber matrix interface as a result of good bonding between fibers and matrix. In case of unidirectional orientation; during applying the non dental glass fiber into the metallic mold it becomes to contact with boarder of the mold. This may explain why some samples of unidirectional gave lower strength than bidirectional. By the result, it was suggested to available this type of fiber as strip shape for easier manipulation.

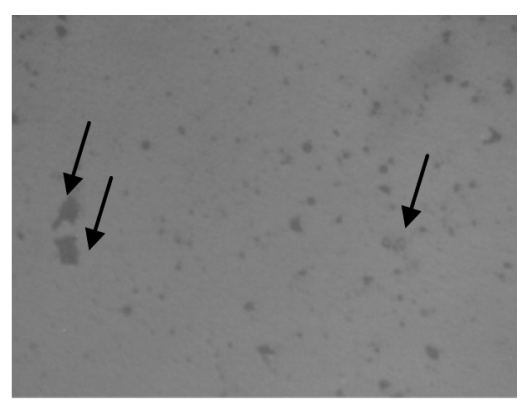

a.roving FRC sample 


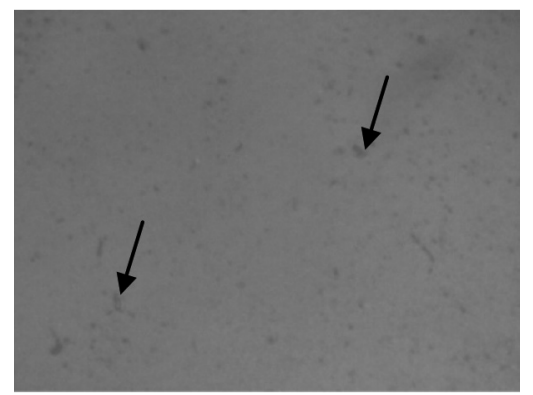

b.woven roving FRC sample

Figure. 2

Optical microscopic result.

(a) Roving FRC shows a lot of voids. ( b)Woven roving shows less voids.

Table 2 showed the means of transverse strength for non dental glass fiber groups which immersed in water for a period of 24 hours and 7 days. By the results it can be said the 24 hours group obtained the highest mean value. This difference may be due to the increase of transferred load to the fibers as a result of the higher adhesion at interface zone between fibers and polymer matrix (Munoz and Manrique. 2015). The Presence of air voids in the matrix allow water to enter inside the fiber reinforced composite and in turn reduce the mechanical properties of FRC. Bidirectional fibers such as woven have reinforcing fibers in two directions by adding toughness to the polymer which acts as crack stoppers (Khan et al., 2015). VanHeumen et al., cit. Mosharraf and Givechian, (2012) stated that the transverse strength of fiber reinforced composite increased by reinforced fibers in certain conditions and the fiber orientation is more important than the fiber type. Vallittu, cit. Mosharraf and Givechian, (2012). believed that with the change in orientation of the fiber; it does effect the mechanical properties of composite sample but it does not have a significant effect of the transverse strength of methyl methacrylate.

In addition, with the period of 7 days immersion we noticed that there are some samples achieved a good transverse strength. It could be as a result of swelling of the fibers which can fill up the gaps between fibers and matrix, thus, increasing the bonding between them which give increasing of mechanical properties (Munoz and Monrique, 2015). As it is well known, the water sorption affect the mechanical properties of fiber reinforced composite. There are some samples obtained lower transverse strength as a result of water sorption. This decrease in transverse strength of fiber reinforced composite samples is related to two facts. The first fact is that, reversible reduction in the mechanical properties of FRC is caused by plasticiztion of the polymer matrix by the molecules of water. The second fact is the fiber polymer matrix bond can be destroyed by the water which results in an irreversible reduction of the strength of fiber reinforced composite. Silane promoted adhesion between the polymer matrix and glass fiber is weakened by leaching of glass forming oxides from the fiber surface and by hydrolytic degradation of the polysiloxane network (Abdulmajeed et al., 2011).

Transverse strength test also carried out for 6 samples of commercial fiber (dental glass fiber) reinforced composite to compare the mean of this group with the mean of non dental glass group as in Table 2 and Table 5. The mean of transverse strength for non dental glass fiber specimens which immersed in water for 24 hours was $152.998 \pm 8.767 \mathrm{MPa}$ for roving orientation and for woven roving orientation the mean was $178.436 \pm 23.362 \mathrm{MPa}$. The mean for dental glass specimens was $167.065 \pm 7.328 \mathrm{MPa}$. It can be said that the woven roving non dental glass fiber reinforced composite achieved high transverse strength. For roving non dental glass fiber reinforced composite group and dental glass fiber reinforced composite group there is different transverse strength but according to the mean of groups the different is not significant. Occlusion need for bridge restoration in anterior area must be capable with stand up to $232 \mathrm{MPa}$ and for posterior area 305 $\mathrm{MPa}$ (Anusavice, 2003). Based on the requirement, it is still need to improvement the FRC construction. The requirement can be done by available the non-dental glass fiber as impregnation fiber and strip shape.

Based on the laboratory condition of this study, it can be concluded that, There is different transverse strength between roving and woven roving non-dental glass fiber reinforced composite. The woven roving non-dental glass 
fiber reinforced composite achieved transverse strength higher than the roving non-dental glass fiber reinforced composite.

\section{ACKNOWLEDGEMENT}

This research is supported by the Ministry of higher education and scientific researchLibya.

\section{BIBLIOGRAPHY}

Abdulmajeed, A.A., Narhi, T.O., Vallitu, P.K., and Lassila L.V., 2011, The Effect of High Fiber Fraction on Some Mechanical Properties of Unidirectional Glass Fiber-Reinforced Composite. J. Dent. Materials. 27 : 313-321.

Anusavice, K.J., 2003, Philips' Science of Dental Materials. $11^{\text {th }}$. Elsevier Science. USA. 89- 144.

Butterworth, C. Ellakwa, A. E. and Shortall, A. 2003. "Fibre-reinforced composites in restorative dentistry," Dental Update. 30(6):300-306. View at Scopus.

Hull, D. and Clyne, T.W. 1996. An introduction to composite materials. Cambridge University Press, Cambridge.

ISO 10477., 2004, Dentistry-Polymer-Based Crown and Bridge Materials. $2^{\text {nd }} \mathrm{ed}$. International Organization for Standarization, Geneva, Switzerland.

Khan, A.S , Azam M. T , Khan, M. Mian,S.A. Rehman, I. Ur. 2015. An update on glass fiber dental restorative composites: A systematic review. Materials Science and Engineering $C$. Elsevier. 47:26-39.

Kim, S.H. and Watts, D.C. 2004. The effect of reinforcement with woven E-glass fibers on the impact strength of complete denture fabricated with high-impact acrylic resin. J Prosthet Dent. 91:274-80.

Loughran, G.M., Versluis, A. and Douglas, W.H. 2005. Evaluation of subcritical fatigue crack propagation in a restorative composite. Dent Mater. 21(3): 252-261.
Mallick, P.K. 2008. Fiber-reinforced composites: materials, manufacturing, and design, 3rd edn. CRC Press, Taylor \& Francis Group, Boca Raton, FL.

Moshrraf, R., Givechian, P. Effect of fiber position and orientation on flexural strength of fiber reinforced composite. Journal of Islamic Dental Association of IRAN (JIDAI). 24 (1): 21-27.

Munoz, E., Manrique, J.A.G.2015. Water Absorption Behaviour and Its Effect on the Mechanical Properties of Flax Fiber Reinforced Bioepoxy Composite. International Journal of Polymer Science.1-10.

Starr, T.F. 1995. Carbon and High Performance Fiber, Directory and Databook, 6th ed, Chapman and Hall, London.

Tanwer. A.K. 2014. Mechanical Properties Testing of and Bi-directional Glass Fiber Reinforced Epoxy Based Composites. International Journal of Research in Advanced Technology, 2 (11): 34-39.

Tezvergil, A., Lassila, L.V.J. and Vallittu, P.K. 2003. The effect of fiber orientation on the thermal expansion coefficient of fiber reinforced composites. Dent. Mater. 19:471-477.

Unalan, F., Dikbas, I. and Gurbuz, O. 2010. Transverse Strength of Polymethylmethacrylate Reinforced with Different Forms and Concentrations of E-Glass Fibres. OHDMBSC. IX: (3): 144-147.

Uzun, G., Hersek, N. and Tincer, T.1999. Effect of five woven fiber reinforcements on the impact and transverse strength of a denture base resin. J Prosthet Dent. 81: 616-20.

Van Heumen, C., Creugers, N.H.J. and Kreulen, C.M. 2010. Thesis Fiberreinforced adhesive bridges-Clinical and laboratory performance. Chapter 1 Radboud Repository of the Radboud University Nijmegen. p1-14. 